\title{
Evaluation of antibacterial potential of the leaves, flowers and bulbs of Allium neapolitanum cirillo
}

Sana Malik ${ }^{1}$, Muhammad Saleem Khan ${ }^{1}$, Muhammad Anwar Sajad ${ }^{1 *}$ Barkatullah $^{1}$, Ghulam Saddiq ${ }^{2}$, Zaib-Un-Nisa ${ }^{3}$, Masaud Shah ${ }^{1}$ and Noor Aziz ${ }^{1}$

1. Department of Botany, Islamia College Peshawar (A Public Sector University), Khyber Pakhtunkhwa-Pakistan

2. Department of Physics, Islamia College Peshawar (A Public Sector University), Khyber Pakhtunkhwa-Pakistan

3. Department of Botany, Women University, Swabi, Guloo-Dheri Swabi-Topi Rd, 23430 Khyber Pakhtunkhwa-

Pakistan

*Corresponding author's email: sajad.khan92@yahoo.com

Citation

Sana Malik, Muhammad Saleem Khan, Muhammad Anwar Sajad, Barkatullah, Ghulam Saddiq, Zaib-Un-Nisa, Masaud Shah and Noor Aziz. Evaluation of antibacterial potential of the leaves, flowers and bulbs of Allium neapolitanum cirillo. Pure and Applied Biology. Vol. 8, Issue 3, pp2076-2086. http://dx.doi.org/10.19045/bspab.2019.80152

Received: 08/05/2019 Revised: 13/07/2019

Accepted: 17/07/2019

Online First: 24/07/2019

\section{Abstract}

The plant extracts are potential sources of modern antimicrobial compounds, especially against bacterial pathogens. In the current research, the whole plant of Allium neapolitanun was screened out to determine their antibacterial potential. The antibactrial activities were observed in different extracts of leaves, flowers and bulbs with different concentrations against four bacterial strains. For Bacillus subtillis, the ethanolic extracts of bulbs showed highest $31.5 \%$ inhibition followed by flowers and leaves at $6 \mu \mathrm{l} / \mathrm{ml}$ concentrations. The flowers showed highest inhibition $34.74 \%$ and $46.9 \%$ followed by leaves and bulbs at the $12 \mu \mathrm{l} / \mathrm{ml}$ and $18 \mu \mathrm{l} / \mathrm{ml}$ concentrations respectively. For Escherichia coli, among the ethanolic extracts, only bulbs showed highest $44.3 \%$ inhibition at 6 $\mu \mathrm{l} / \mathrm{ml}$. Bulb also showed highest inhibition at $12 \mu \mathrm{l} / \mathrm{ml}$ concentration followed by leaves and flowers. However, highest $60 \%$ inhibition was shown by flowers followed by bulbs and leaves at $18 \mu \mathrm{l} / \mathrm{ml}$ concentrations while at $12 \mu \mathrm{l} / \mathrm{ml}$ concentration the highest $41.9 \%$ inhibition was shown by leaves followed by flower. For Klebsiella pneumonia and Xanthomonas species, among the ethanolic extracts, the highest inhibition was shown by bulbs $38.13 \%, 38.9 \%$ followed by flowers at $6 \mu \mathrm{l} / \mathrm{ml}$ concentrations. Similarly, the highest inhibition was also shown by bulbs $40.5 \%$ and $37.03 \%$, followed by flowers and leaves at $12 \mu \mathrm{l} / \mathrm{ml}$ concentrations while the highest $56.09 \%$ inhibition was shown by flowers followed by leaves and bulbs at $18 \mu \mathrm{l} / \mathrm{ml}$ concentrations. The highest $43.03 \%$ and $45.7 \%$ inhibition was shown by flowers followed by leaves and bulbs at 12 $\mu \mathrm{l} / \mathrm{ml}$ concentrations while at $18 \mu \mathrm{l} / \mathrm{ml}$ concentration the highest but same inhibition (46.32\%) was shown by leaves and flowers, followed by bulbs. Among the methanolic extracts, no activity was observed at $6 \mu \mathrm{l} / \mathrm{ml}$ concentrations for all bacterial strains.

Keywords: Antibacterial activities; Bacterial strains; Ethanolic and methanolic extracts 


\section{Introduction}

Infectious diseases also called transmissible or contagious or communicable diseases involve clinically obvious illness, resulting from the infection, presence and growth of pathogenic biological agents in an individual host organism. Infectious pathogens include bacteria, protozoa, multicellular parasites, fungi, virus and unusual and abnormal proteins called prions. Currently, a large number of antimicrobial agents are used in order to eliminate the infectious pathogens and prevent infections [1]. Plants are endowed with secondary metabolites such as terpenoids, flavonoids, tannins and alkaloids. Medicinal plants may present a rich source of antiviral, antifungal and antibacterial activities [2]. To avoid the side effects of antibiotics, the scientists are analyzing numerous plant families viz Asteraceae, Apocynaceae, Caesalpiniaceae, Piperaceae, Sapotaceae, Bigonaceae, Liliaceae, Solanaceae, Rutaceae, Amaranthaceae etc to find new antimicrobial agents from the extracts of these plants for the cure of various diseases [3]. The primary benefits of using herbal medicines are safer as compared to synthetic alternatives, offering remarkable therapeutic benefits and more cheap treatment [4]. Thus, over $50 \%$ of these modern drugs have been originated from natural products and these natural products play a crucial role in drug development in pharmaceutical industry [5]. Generally, bacteria have the genetic ability to transfer and gain resistance to drugs used as therapeutic agents. The only way to inhibit antibiotic resistance is to use new compounds which are not based on the existing synthetic antimicrobial agents [6]. Plants serve as a rich source of antimicrobial agents [7]. The spreading of drug resistant pathogens is one of the most severe threats to the successful treatment of microbial diseases. The essential oils and phytochemicals of plant extracts such as flavonoids, phenolics, steroids, tannins and alkaloids have provoked interest as a source of natural products. The screening of antimicrobial potential of medicinal plants is an alternative remedy to cure various infectious diseases [8]. A large part of the human world population relies on folk remedies for basic health care. Medicinal and fragrant plant species which are generally utilized for medicinal purposes are the main sources of natural organic substances. Plants possess the potentiality to synthesize fragrant substances and most of which are phenols and their oxygenated derivatives. The phytochemicals have been reported to possess antifungal, insecticidal, antioxidant, antibacterial and antiviral activities [9]. Currently, multiple drug resistance has increased because of the extensive utilization of commercial antimicrobial remedies generally used in the cure of contagious illness [10]. Likewise, antibiotics may also sometimes cause detrimental effects on the host such as hypersensitivity, immune suppression and allergic reactions [11]. Numerous adverse effects were marked in patients using allopathic drugs for curing diseases. So the scientists concentrated on to develop new antimicrobial agents from medicinal plants. Herbal drugs are affordable and have very few side effects. Hence, there is a need to discover alternative antimicrobial drugs from medicinal plants for the cure of infectious diseases [12].

The genus Allium is the largest genus of the family Alliaceae and has almost more than 700 species spread all over the Asia, Africa and Eurpoe, each varying in taste, structure and colour, but resemble in biochemical, phytochemicals and nutraceutical content [13]. The genus Allium is an essential dietary source of antioxidant phytochemical compounds which have the ability to scaveng free radicals: organosulfer compounds, phytoalexin (e.g. allixin), flavonoids, trace of elements such as calcium, zinc, germanium, selenium and volatile oil having sulphur 
constituents [14]. Many sulphur compounds found in Allium species are responsible for various biological properties such as antimicrobial [15] antioxidant, hypolipidaemic, antithrombotic, antiprotozoal antihypertensive and hepatoprotective properties [16]. Allium is medicinal genus enriched in carbohydrates and organic-sulphur compounds such as Allicin (a precursor for the production of saponins, glycosides and alkaloids). Numerous phytochemicals have been obtained from different species of this genus, but only a few (allinase and ajoene) are active Materials and methods

\section{Collection of plant}

The whole plant of Allium neapolitanum Cirillo was collected from the botanical garden of Islamia College Peshawar in the month of April 2018. The plant was confirmed by Dr. Barkatullah and Dr. Naveed Akhtar (Assistant Professors, Department of Botany, Islamia College Peshawar). The collected fresh plants were packed in bags and then shade-dried for 3-4 weeks.

\section{Drying}

The plants were properly dried under shade at room temperature. After 3-4 weeks, when the plants completely got dried then the required plants were separated from weeds, grasses and other species which were mixed with the required plant during collection and then the different parts of Allium neapolitanum viz., leaves, flowers and bulbs were also separated from each other. The dried leaves, flowers and bulbs were separately ground in an electric grinder for about an hour. The dried plant material was then refined to get fine powder and then each part was preserved in a separate bottle [19].

\section{Extraction}

The procedure used by Nisa et al. [19] was followed for the extraction of plant materials. About 100 grams of the powdered material of each part (leaves, flowers, bulbs) was soaked separately in $400 \mathrm{ml}$ ethanol and $400 \mathrm{ml}$ as pesticides. The phenol and sulphur containing allelopathic compounds of genus Allium may be used for weeds and insects management in agricultural practices [17]. The great anti hypertensive effects of the aqueous extracts of bulbs of $A$. neapolitanum could be related to synergy with adrenergic receptor B2 antagonist, involved in regulation of blood pressure [18]. The main objective of this work is to determine the antibacterial potential of the ethanolic and methanolic extracts of the leaves, flowers and bulbs of Allium neapolitanum Cirillo.

methanol and kept in shaker for about 48 hours. The material was then passed from filter paper in order to get crude extract. The crude extracts were put in the rotary vacuum evaporator for the evaporation of ethanol and methanol. In this way, the extracts were concentrated under reduced pressure using rotary evaporator at temperature below $60{ }^{\circ} \mathrm{C}$. Finally, the extracts were suspended in water bath for 3-4 days until complete evaporation of ethanol and methanol in order to get concentrated extracts to perform various activities.

\section{Antimicrobial activities}

The antimicrobial test was carried out by well diffusion method [20]. The ethanolic and methanolic extracts of the leaves, flowers and bulbs of Allium neapolitanum were tested against four bacterial strains.

\section{Bacterial strains used}

To determine the antibacterial potential of Allium neapolitanum, the following four bacterial strains were used:

Escherichia coli, Bacillus subtillis, Klebsella pneumonia, Xanthomonas species.

\section{Media used}

\section{Nutrient broth}

Nutrient broth was used for the growth and multiplication of bacterial strains. It is a general-purpose liquid basal medium composed of nutrients (such as beef extracts and peptone) which allows many types of 
microorganisms to grow. It is used for the general maintenance of cultures. Because it supports the growth of most bacteria, it is often used as a basic medium modified for biochemical tests.

\section{Preparation of nutrient broth}

For four bacterial strains, nutrient broth was made by dissolving 1.04 gm nutrient broth in $80 \mathrm{ml}$ of distilled water $(1.3 \mathrm{gm}$ for $100 \mathrm{ml}$ distilled water). It was properly shocked and boiled for one minute to completely dissolve the medium. The nutrient broth was then sterilized along with four flasks in autoclave at $121^{\circ} \mathrm{C}$ for about 45 minutes.

\section{Inoculation of bacterial strains}

After sterilization, about $20 \mathrm{ml}$ of nutrient broth was poured in each of the sterilized flask and then allowed to cool at room temperature for a few minutes. The flasks were labeled. After cooling, bacterial strains were inoculated in each of the labeled flask with the help of a streaking loop. The streaking loop was heated on spirit lamp after inoculation of each strain to avoid contaminations. After inoculation, the flasks were covered with aluminum foil and then kept in incubator for 24 hours. The process of inoculation was carried out in laminar flow hood.

\section{Dilution of nutrient broth}

After 24 hours, fresh nutrient broth was prepared according to the above procedure and sterilized along with 4 flasks in autoclave for about 45 minutes. After sterilization, about $10 \mathrm{ml}$ of freshly prepared nutrient broth was taken in each of the sterilized flask and each was mixed with $10 \mathrm{ml}$ taken from previously prepared inoculated nutrient broth. The antibacterial activity was then performed on this mixture of fresh and previously inoculated nutrient broth.

\section{Mueller-Hinton Agar (MHA)}

MHA is a microbiological medium that is used for antimicrobial susceptibility testing. It was used for antibacterial activity.

\section{Preparation of MHA}

For ethanolic and methanolic extracts of flowers, leaves and bulbs of Allium neapolitanum, MHA was prepared by dissolving $79.8 \mathrm{gm}$ of MHA in $2100 \mathrm{ml}$ distilled water $(38 \mathrm{gm}$ for $1000 \mathrm{ml}$ or $1 \mathrm{~L}$ distilled water). It was shacked well and boiled for a few minutes until the medium was completely dissolved. The completely dissolved medium along with 84 petridishes was then sterilized in the autoclave machine at $121^{\circ} \mathrm{C}$ for about 45 minutes.

\section{Preparation of DMSO solution}

About $0.50 \mathrm{gm}$ of each extract was dissolved in $3000 \mu \mathrm{l}$ dimethylsulphoxide (DMSO) and then properly shocked. It was to be used later in antimicrobial test.

\section{DMSO (Negative Control)}

DMSO was used as a negative control.

\section{Ciprofloxacin (Positive Control)}

It is a broad spectrum antibiotic which is used against both gram positive and gram negative bacteria. It was used as a standard or positive control. The results of negative control were compared with those of positive control.

\section{Antibacterial test}

After sterilization, about $25 \mathrm{ml}$ of medium was poured in each of the sterilized petri dishes and allowed to cool and solidify at room temperature. Bacterial strains were cultured on the media with the help of cotton buds. After swabbing, wells were made in the media with the help of a sterilized cork borer. Three wells were made in each petridish. The cork borer was heated on spirit lamp for each bacterial strain to avoid contamination. The DMSO solution was poured in the wells with the help of a sterilized micropipette. Three concentrations of DMSO of each extract were used (i.e., 6ul, 12ul, 18ul). This whole activity was performed in the laminar flow hood. The petridishes were then transferred carefully to incubator and kept there for about 24 hours.

Measurement of zone of inhibition

The clear region around the well on the agar 
surface, is called zone of inhibition. The clear region is an indication of the absence, or the effective inhibition of microbial growth by the antimicrobial agent. The zone of inhibition was measured by measuring the diameter (in millimeters) of clear region with the help of a scale.

\section{Results and discussion}

Plant extracts have been used for many thousands of years in food preservation and pharmaceuticals. It is necessary to survey those plants, theoretically which have been used in traditional medicine to modify the quality of healthcare. The plant extracts are potential sources of modern antimicrobial compounds, especially against bacterial pathogens. In vitro studies showed that the plant extracts have variable effects [21]. In the current study, the whole plant of Allium neapolitanun was screened out to determine their antibacterial potential.

The antimicrobial activity of the ethanol and methanolic extracts of the leaves, flowers and bulb of Allium neapolitanum - Cirillo against human pathogenic bacteria, Escherichia coli, Bacillus subtillis, Klebsiella pneumonia and Xanthomonas were measured by measuring the zone of inhibition in disc diffusion method. The organisms used and zone of inhibition to the corresponding extracts are shown in (Tables 1-8). Antibacterial activity at different doses was done by disc diffusion method. Activity was dependent on the dose of the tested material. As the concentration increased the zone of inhibition was also increased. Similar results were also observed with Kowti et al. [22] using different strains of bacteria. Overall results showed that ethanol is a very good solvent compared to methanol.

For B. subtillis, the ethanolic extracts of leaves showed antibacterial activities with zone of inhibition $8.66 \mathrm{~mm}, 10 \mathrm{~mm}$ and $11.33 \mathrm{~mm}$ at the concentrations of $6 \mu \mathrm{l} / \mathrm{ml}, 12$ $\mu \mathrm{l} / \mathrm{ml}$ and $18 \mu \mathrm{l} / \mathrm{ml}$ respectively. The ethanolic and methanolic extracts of flowers showed antibacterial activities with zone of inhibition $9.33 \mathrm{~mm}, 11 \mathrm{~mm}$ and $15 \mathrm{~mm}$ at the concentrations of $6 \mu \mathrm{l} / \mathrm{ml}, 12 \mu \mathrm{l} / \mathrm{ml}$ and 18 $\mu \mathrm{l} / \mathrm{ml}$ respectively. Ethanol flower extract showed more potency than the leaf extract. The ethanolic extracts of bulbs showed antibacterial activities with zone of inhibition $9.66 \mathrm{~mm}, 9.66 \mathrm{~mm}$ and $11 \mathrm{~mm}$ at the concentrations of $6 \mu \mathrm{l} / \mathrm{ml}, 12 \mu \mathrm{l} / \mathrm{ml}$ and 18 $\mu 1 / \mathrm{ml}$ respectively as shown in the table 1 . Similar results were reported by Singh [23] that the garlic extract is more effective against $S$. aureus as compared to E. coli. Amber et al. [24] also reported that the Allium sativum as therapeutically active against bacterial pathogens. Similarly, the methanolic extracts of leaves and flowers showed antibacterial activities only at the concentration of $18 \mu \mathrm{l} / \mathrm{ml}$ with zone of inhibition $13 \mathrm{~mm}$ and $13.66 \mathrm{~mm}$ respectively. While bulbs showed antibacterial activities at the concentrations of $12 \mu \mathrm{l} / \mathrm{ml}$ and $18 \mathrm{ul}$ with zone of inhibition $11.66 \mathrm{~mm}$ and $12.33 \mathrm{~mm}$ respectively as shown in the table 2 . Our results are in agreement with the findings of Kowti et al.[22].

In case of $E$. coli, the ethanolic extracts of leaves and flowers showed antibacterial activities only at the concentrations of 12 $\mu \mathrm{l} / \mathrm{ml}$ and $18 \mu \mathrm{l} / \mathrm{ml}$ with zone of inhibition 10 $\mathrm{mm}, 12.33 \mathrm{~mm}$ and $9.33 \mathrm{~mm}$ and $15 \mathrm{~mm}$ respectively. The ethanolic bulbs showed antibacterial activities at all of the given concentrations with zone of inhibition 10.33 $\mathrm{mm}, 10.66 \mathrm{~mm}$ and $13 \mathrm{~mm}$ as shown in the table 3. These findings are in agrement with the results of Masoodi et al. [25]. The methanolic extracts of leaves and flowers showed antibacterial activities at the concentrations of $(12 \mu \mathrm{l} / \mathrm{ml}$ and $18 \mu \mathrm{l} / \mathrm{ml})$ with zone of inhibition $(10.33 \mathrm{~mm}$ and 11.66 $\mathrm{mm})$ and $(10 \mathrm{~mm}$ and $14 \mathrm{~mm})$ respectively. The methanolic extracts of bulbs showed antibacterial activities only at the concentration of $18 \mu \mathrm{l} / \mathrm{ml}$ with zone of inhibition $12.66 \mathrm{~mm}$ as shown in the table 4 . 
it was observed that increase in concentration also increased zone of inhibition. Similar results were also reported by Cheruiyot et al., [26].

For $K$. pneumonia, the ethanolic extract of leaves showed antibacterial activities at the concentrations of $12 \mu \mathrm{l} / \mathrm{ml}$ and $18 \mu \mathrm{l} / \mathrm{ml}$ with zone of inhibition $9.3 \mathrm{~mm}$ and $12 \mathrm{~mm}$ respectively. It was found that the ethanolic extract of flowers act in antibacterial activities even at low $(6 \mu \mathrm{l} / \mathrm{ml})$ concentration $8.33 \mathrm{~mm}$ inhibition zone. Though, at concentration $12 \mu \mathrm{l} / \mathrm{ml}$ and $18 \mu \mathrm{l} / \mathrm{ml}$ showed $8.33 \mathrm{~mm}, 9.66 \mathrm{~mm}$ and $15.33 \mathrm{~mm}$ zone of inhibition respectively. The ethanolic extract of bulbs showed antibacterial activities at 6 $\mu \mathrm{l} / \mathrm{ml}$ with zone of inhibition $9.66 \mathrm{~mm}$ followed by $12 \mu \mathrm{l} / \mathrm{ml}$ and $18 \mu \mathrm{l} / \mathrm{ml}$ with zone of inhibition $10.66 \mathrm{~mm}$ and $11.33 \mathrm{~mm}$ respectively as shown in the table 5. However the findings of Siddiqui et al. [27] are not matching with our results but they use different specie of Allium. It might be due to this reason. According to him, on ethanolic extract of Allium cepa against five pathogenic cultures revealed significant activity against the tested pathogens. Non significant results were observed among the methanolic extracts of leaves, flowers and bulbs which showed antibacterial activities at the concentrations of $12 \mu \mathrm{l} / \mathrm{ml}$ and $18 \mu \mathrm{l} / \mathrm{ml}$ with zone of inhibition $10.66 \mathrm{~mm}$ and $12.66 \mathrm{~mm}, 11.33$ $\mathrm{mm}$ and $12.66 \mathrm{~mm}$ and $10.33 \mathrm{~mm}$ and 12.33 $\mathrm{mm}$ respectively, as shown in the table 6 . It is clear from these results that all the three samples (leaves, flowers and bulbs) have approximately similar efficiency against bacterial pathogens but not active at low concentration $(6 \mu \mathrm{l} / \mathrm{ml})$. Bacterial responses to plant extracts are concentration-dependent. At high concentrations, the active compounds of plant exhibit antimicrobial activities while at lower concentrations fail to control the growth of bacteria. Similar results were also proposed by other researchers [25].

In case of Xanthomonas species, no results were observed in ethanolic extracts of leaves with $6 \mu \mathrm{l} / \mathrm{ml}$ and $12 \mu \mathrm{l} / \mathrm{ml}$ concentrations, observed $13 \mathrm{~mm}$ zone of inhibition only at the concentration of $18 \mu \mathrm{l} / \mathrm{ml}$. The ethanolic extracts of flowers showed antibacterial activities at the concentrations of $12 \mu \mathrm{l} / \mathrm{ml}$ and $18 \mu \mathrm{l} / \mathrm{ml}$ with zone of inhibition $9.33 \mathrm{~mm}$ and $13 \mathrm{~mm}$ respectively. While at $6 \mu \mathrm{l} / \mathrm{ml}$ concentrations no zone of inhibition was observed. The ethanolic extracts of bulbs showed antibacterial activities at the concentrations of $6 \mu \mathrm{l} / \mathrm{ml}, 12 \mu \mathrm{l} / \mathrm{ml}$ and 18 $\mu \mathrm{l} / \mathrm{ml}$ with zone of inhibition $9.33 \mathrm{~mm}, 10$ $\mathrm{mm}$ and $11.33 \mathrm{~mm}$ respectively as shown in the table 7. Begum and Yaseen [28] demonstrated the antimicrobial potential of Aqueous, ethanolic and dichloromethane extracts of the bulbs of Allium cepa. All extracts were found active against the selected bacterial species.

The methanolic extracts of leaves, flowers and bulbs showed antibacterial activities at the concentrations of $12 \mu \mathrm{l} / \mathrm{ml}$ and $18 \mu \mathrm{l} / \mathrm{ml}$ with zone of inhibition $10.66 \mathrm{~mm}$ and 12.66 $\mathrm{mm}, 12.33 \mathrm{~mm}$ and $13.33 \mathrm{~mm}$ and $11.66 \mathrm{~mm}$ and $12.66 \mathrm{~mm}$ respectively as shown in the table 8. Similar results were also revealed by Najjaa et al. [29] using three different extracts of bulb, leaf and flower of Allium roseum for antibacterial activity. The negative control, DMSO, did not show any inhibition zone against all the test strains. In addition, the mean growth inhibition zones of all the concentrations of the plant extract were less than that of the positive control group. However, the difference in the maximum growth inhibition zone from that with the negative control group was significant. 
Table 1. Antibacterial potential of ethanolic extracts of the leaves, flowers and bulbs of Allium neapolitanum against Bacillus subtilis

\begin{tabular}{|c|c|c|c|}
\hline Extract (ethanolic) & Concentration $(\boldsymbol{\mu l} / \mathbf{m l})$ & Zone of inhibition $(\mathbf{m m})$ & Inhibition $\%$ \\
\hline \multirow{2}{*}{ Leaves } & 6 & $8.66 \pm 0.58$ & 28.24 \\
& 12 & $10 \pm 1$ & 31.6 \\
& 18 & $11.33 \pm 0.58$ & 35.40 \\
\hline \multirow{2}{*}{ Flowers } & 6 & $9.33 \pm 0.58$ & 30.43 \\
& 12 & $11 \pm 1$ & 34.74 \\
\hline \multirow{2}{*}{ Bulbs } & 18 & $15 \pm 1$ & 31.50 \\
& 6 & $9.66 \pm 0.58$ & 30.51 \\
+Ve control & 12 & $9.66 \pm 0.58$ & 34.4 \\
\hline (Ciprofloxacin) & 18 & $30.66 \pm 1.15$ & $31.66 \pm 1.53$ \\
\hline
\end{tabular}

Table 2. Antibacterial potential of methanolic extracts of the leaves, flowers and bulbs of Allium neapoltanum against Bacillus subtillis

\begin{tabular}{|c|c|c|c|}
\hline Extract (methanolic) & $\begin{array}{c}\text { Concentration } \\
(\boldsymbol{\mu l} / \mathbf{m l} / \mathbf{m l})\end{array}$ & $\begin{array}{c}\text { Zone of inhibition } \\
(\mathbf{m m})\end{array}$ & Inhibition \% \\
\hline \multirow{2}{*}{ Leaves } & 6 & nil & nil \\
& 12 & nil & 40.62 \\
\hline & 18 & $13 \pm 1$ & nil \\
Flowers & 6 & nil & 42.7 \\
& 12 & $13.66 \pm 1.154$ & nil \\
\hline Bulbs & 18 & $11.66 \pm 0.58$ & 36.82 \\
& 6 & $12.33 \pm 0.58$ & 38.53 \\
\hline +Ve control & 12 & $30.66 \pm 1.15$ & \\
\hline
\end{tabular}

Table 3. Antibacterial potential of ethanolic extracts of the leaves, flowers and bulbs of Allium neapolitanum against $E$. coli

\begin{tabular}{|c|c|c|c|}
\hline Extract (ethanolic) & Concentration $(\boldsymbol{\mu l} / \mathbf{m l})$ & Zone of inhibition $(\mathbf{m m})$ & Inhibition $\%$ \\
\hline \multirow{2}{*}{ Leaves } & 6 & nil & nil \\
& 12 & $10 \pm 1$ & 40.55 \\
& 18 & $12.33 \pm 2.516$ & nil \\
\hline \multirow{2}{*}{ Flowers } & 6 & nil & 37.83 \\
& 12 & $9.33 \pm 0.58$ & 40 \\
\hline Bulbs & 18 & $15 \pm 2$ & 43.22 \\
& 6 & $10.33 \pm 0.58$ & 52 \\
\hline +Ve control & 12 & $13 \pm 0.58$ & \\
(Ciprofloxacin) & 18 & $23.33 \pm 0.58$ & $24.66 \pm 0.58$ \\
\hline
\end{tabular}


Table 4. Antibacterial potential of methanolic extracts of the leaves, flowers and bulbs of Allium neapolitanum against $E$. coli

\begin{tabular}{|c|c|c|c|}
\hline Extract (methanolic) & Concentration $(\boldsymbol{\mu l} \mathbf{m} \mathbf{m l})$ & Zone of inhibition $(\mathbf{m m})$ & Inhibition \% \\
\hline & 6 & nil & nil \\
Leaves & 12 & $10.33 \pm 0.58$ & 41.9 \\
& 18 & $11.66 \pm 1.154$ & 46.64 \\
\hline \multirow{2}{*}{ Flowers } & 6 & nil & nil \\
& 12 & $10 \pm 1$ & 40.55 \\
\hline & 18 & $14 \pm 1$ & nil \\
\hline \multirow{2}{*}{ Bulbs } & 6 & nil & nil \\
& 12 & $12.66 \pm 0.58$ & 50.64 \\
\hline +Ve control & 18 & $23.33 \pm 0.58$ & \\
(Ciprofloxacin) & 6 & $24.66 \pm 0.58$ & \\
\hline -Ve control (DMSO) & 12 & $25 \pm 1.73$ & \\
\hline
\end{tabular}

Table 5. Antibacterial potential of ethanolic extract of the leaves, flowers and bulbs of Allium neapolitanum against $K$. pneumonia

\begin{tabular}{|c|c|c|c|}
\hline Extract (ethanolic) & Concentration $(\boldsymbol{\mu l} / \mathbf{m l} / \mathbf{m l})$ & $\begin{array}{c}\text { Zone of inhibition } \\
(\mathbf{m m})\end{array}$ & Inhibition \% \\
\hline \multirow{2}{*}{ Leaves } & 6 & nil & nil \\
& 12 & $9.3 \pm 0.58$ & 35.32 \\
\multirow{2}{*}{ Flowers } & 18 & $12 \pm 4.36$ & 43.90 \\
& 6 & $8.33 \pm 0.58$ & 32.9 \\
& 12 & $9.66 \pm 0.58$ & 36.7 \\
Bulbs & 18 & $15.33 \pm 1.53$ & 56.09 \\
\hline \multirow{2}{*}{ +Ve control } & 6 & $9.66 \pm 0.58$ & 38.13 \\
(Ciprofloxacin) & 12 & $11.66 \pm 0.58$ & 40.48 \\
\hline -Ve control (DMSO) & 6 & $25.33 \pm 0.58$ & \\
\hline
\end{tabular}

Table 6. Antibacterial potential of methanolic extract of the leaves, flowers and bulbs of Allium neapolitanum against $K$. pneumonnia

\begin{tabular}{|c|c|c|c|}
\hline Extracts (methanolic) & Concentration $(\mu \mathrm{l} / \mathrm{ml})$ & Zone of inhibition (mm) & Inhibition \% \\
\hline Leaves & $\begin{array}{c}6 \\
12 \\
18 \\
\end{array}$ & $\begin{array}{c}\text { nil } \\
10.66 \pm 0.58 \\
12.66 \pm 0.58 \\
\end{array}$ & $\begin{array}{c}\text { nil } \\
40.48 \\
46.32 \\
\end{array}$ \\
\hline Flowers & $\begin{array}{c}6 \\
12 \\
18 \\
\end{array}$ & $\begin{array}{c}\text { nil } \\
11.33 \pm 1.154 \\
12.66 \pm 0.58 \\
\end{array}$ & $\begin{array}{c}\text { nil } \\
43.03 \\
46.32 \\
\end{array}$ \\
\hline Bulbs & $\begin{array}{c}6 \\
12 \\
18 \\
\end{array}$ & $\begin{array}{c}\text { nil } \\
10.33 \pm 0.58 \\
12.33 \pm 0.58 \\
\end{array}$ & $\begin{array}{c}\text { nil } \\
39.23 \\
45.12 \\
\end{array}$ \\
\hline $\begin{array}{c}\text { +Ve control } \\
\text { (Ciprofloxacin) }\end{array}$ & $\begin{array}{c}6 \\
12 \\
18\end{array}$ & $\begin{array}{l}25.33 \pm 0.58 \\
26.33 \pm 3.21 \\
27.33 \pm 0.58\end{array}$ & \\
\hline -Ve control (DMSO) & & & \\
\hline
\end{tabular}


Table 7. Antibacterial potential of ethanolic extract of the leaves, flowers and bulbs of Allium neapolitanum against Xanthomonas

\begin{tabular}{|c|c|c|c|}
\hline Extract (ethanolic) & Concentration (a) & Zone of inhibition (mm) & Inhibition \% \\
\hline & 6 & nil & nil \\
Leaves & 12 & nil & nil \\
& 18 & $13 \pm 1$ & nil \\
\hline \multirow{2}{*}{ Flowers } & 6 & nil & 34.55 \\
& 12 & $9.33 \pm 0.58$ & 36.8 \\
\hline & 18 & $13 \pm 1.732$ & 38.9 \\
Bulbs & 6 & $9.33 \pm 0.58$ & 37.03 \\
& 12 & $10 \pm 0$ & 32.06 \\
\hline +Ve control & 18 & $11.33 \pm 0.58$ & \\
(Ciprofloxacin) & 12 & $24 \pm 2$ & \\
\hline -Ve control (DMSO) & 18 & $35.33 \pm 1.53$ & \\
\hline
\end{tabular}

Table 8. Antibacterial potential of methanolic extract of the leaves, flowers and bulbs of Allium neapolitanum against Xanthomonas

\begin{tabular}{|c|c|c|c|}
\hline Extrac (methanolic) & Concentration $(\mu \mathrm{l} / \mathrm{ml})$ & Zone of inhibition (mm) & Inhibition \% \\
\hline Leaves & $\begin{array}{c}6 \\
12 \\
18\end{array}$ & $\begin{array}{c}\text { nil } \\
10.66 \pm 0.58 \\
12.66 \pm 1.527\end{array}$ & $\begin{array}{c}\text { nil } \\
39.5 \\
35.83\end{array}$ \\
\hline Flowers & $\begin{array}{c}6 \\
12 \\
18 \\
\end{array}$ & $\begin{array}{c}\text { nil } \\
12.33 \pm 1.154 \\
13.33 \pm 1.527\end{array}$ & $\begin{array}{c}\text { nil } \\
45.5 \\
37.72 \\
\end{array}$ \\
\hline Bulbs & $\begin{array}{c}6 \\
12 \\
18 \\
\end{array}$ & $\begin{array}{c}\text { nil } \\
11.66 \pm 0.58 \\
12.66 \pm 0.58\end{array}$ & $\begin{array}{c}\text { nil } \\
43.19 \\
35.83 \\
\end{array}$ \\
\hline $\begin{array}{c}\text { +Ve control } \\
\text { (ciprofloxacin) }\end{array}$ & $\begin{array}{c}6 \\
12 \\
18\end{array}$ & $\begin{array}{c}24 \pm 2 \\
27 \pm 2.64 \\
35.33 \pm 1.53\end{array}$ & \\
\hline -Ve control (DMSO) & & & \\
\hline
\end{tabular}

\section{Conclusion and recommendations}

The results of antimicrobial tests of the ethanolic and methanolic extracts of the leaves, flowers and bulbs of Allium neapolitanum suggested that the organic solvents (ethanol and methanol) possess the ability to extract the important phytoconstituents. However, the ethanolic extracts showed best antimicrobial activities as compared to methanolic extracts. Hence, keeping in view the results, it may be concluded that Allium neapolitanum has the potential to provide resistance against most of the tested microbes. Moreover, the antimicrobial activities were found to be increased with increasing concentrations and that is why best results were shown at the concentration of $18 \mu \mathrm{l} / \mathrm{ml}$ as compared to 6 $\mu \mathrm{l} / \mathrm{ml}$ and $12 \mu \mathrm{l} / \mathrm{ml}$. As Allium neapolitanum is a rich source of important active constituents as well as possessing antimicrobial potential against most of the tested bacterial strains so that this plant may be used in antibiotics as well as for medicinal purposes. Moreover, in addition to ethanol and methanol, other organic solvents may also be used for extraction in order to get varying results. 


\section{Authors' contributions}

Conceived and designed the experiments: MS Khan \& MA Sajad, Performed the experiments: S Malik, Analyzed the data: Barkatullah, ZU Nisa \& MA Sajad Contributed materials/ analysis/ tools: MS Khan, M Shah, N Aziz \& G Saddiq. Wrote the paper: S Malik, MA Sajad \& ZU Nisa.

\section{Acknowledgment}

Authors are thankful to the chairman, Department of Botany, Islamia College Peshawar for providing facilities for the research work.

\section{References}

1. Nadkarni AK \& Nadkarni KM (1998). Indian Material Medica. $1^{\text {st }}$ edn, Popular book deport. Bombay India.

2. Wilcox JK, Ash SL \& Catignani GL (2004). Antioxidants and prevention of chronic diseases. Crit Rev Food Sci Nutr 44(4): 275-295.

3. Sharma AK (2013). Medicinal properties of apamarg (Acyranthes aspera). Int J Ayur Pharma Res 1(3): 4-12.

4. Ahmad I \& Beg AZ (2001). Antimicrobial and phytochemical studies on 45 Indian medicinal plants against multi-drug resistant human pathogens. J Ethnopharmacol 74: 113123.

5. Jeyachandran R \& Mahesh A (2007). Antimicrobial evaluation of Kigelia africana. J Microbiol 2(8): 645-649.

6. Shah PM (2005). The need for new therapeutic agents: what is in pipeline? Clin Microbiol Infect 11: 36-42.

7. Schafer H \& Wink M (2009). Medicinally important secondary metabolites in recombinant microorganisms or plants: progress in alkaloid biosynthesis. Biotechnol $J$ 4(12): 1684-1703.

8. Tepe B, Daferera D, Sokmen M, Pollissiou M \& Sokmen A (2004). In vitro antimicrobial and antioxidant activities of the essential oils and various extracts of Thymus eigii. $J$ Agric Food Chem 52: 1132-1137.

9. Kordali S, Kotan R, Mavi A, Cakir A, Ala A \& Yildirim A (2005). Determination of chemical composition and antioxidant activity of the essential oil of Artemisia dracunculus and of the antibacterial and antifungal activities of Turkish Artemisia absinthium, Artemisia dracunculus, Artemisia santonicum and Artemisia spicegera essential oils. J Agric Food Chem 53: 9452-9458.

10. Service RF (1995). Antibiotics that resist resistance. J Sci 270: 724-727.

11. Ahmad I, Mehmood Z \& Mohammad F (1998). Screening of some Indian medicinal plants for their antimicrobial properties. J Ethnopharmacol 62: 183193.

12. Cordell GA (2000). Biodiversity and drug discovery: a symbiotic relationship. Phytochem 55: 463-480.

13. Hirschegger P, Jakse J, Trontelj P \& Bohanec B (2010). Origin of Allium ampeloprasum horticultural groups and a molecular phylogeny of the section Allium. Mol Phylogenet Envol 54 : 488497.

14. Lanzotti V (2006). The analysis of onion and garlic. J Chromatogr A 1112(1-2): 3-22.

15. Castello, MC, Anita P, Naresh C \& Madhuri S (2002). Antimicrobial activity of crude extracts from plant parts and corresponding Calli of Bixaorellina. Indian J Exp Biol 40: 1378-1381.

16. Tapiero H, Townsend D \& Tew K (2004). Organosulpher compounds from Alliaceae in the prevention of human pathologies. Biomed Pharmacother 58: 183-193.

17. Yousaf Z, Umer A, Younas A, Khan F \& Wang Y (2012). Allelopathic plants: 24. Genus Allium L. Allelopathy J 29(1): 112.

18. Nencini C, Franchi GG \& Micheli L 
(2010). Cardiovascular receptor binding affinity of aqueous extracts from Allium species. J Food Sci Technol 61: 433-439.

19. Nisa ZU, Shah SH, Farooq G, Sajad MA \& Khan MAS (2019). Identification, quantification and comparative assessment of costunolide in wild, cultivated and in vitro callus culture of Saussurea lappa by HPLC technique. Pure Appl Biol 8(1): 910-919.

20. Jan AK, Shah MR, Anis I \& Marwat IK (2009). In-vitro antifungal and antibacterial activities of extracts of Galium tricornutum subsp. Longipedunculatum. J Enzyme Inhib Med Chem 24 : 192-196.

21. Gu-hua XU, Xin-kui XIA \& Youg-lei LIU (2011). "Extraction and antimicrobial activity of the components from Chenopodium album Linn. Hubei Agric Sci 22-28.

22. Kowti R, Harsha R, Ahmed MG, Hareesh AR, Thammanna Gowda SS, Dinesha R, Satish Kumar BP, \& Irfan AM (2010). Antimicrobial activity of ethanol extract of leaf and flower of Spathodea campanulata P. Beauv. Res J Pharm Biol Chem Sci 1: 691-698.

23. Singh S (2018). Studies on antimicrobial and phytochemical properties of Allium sativum extracts. Int J Innov Res Sci Eng Technol 7(5).

24. Amber R, Adnan M, Tariq A, Khan SN,
Mussarat S, Hashem A, Al-huqail AA, Al-Arjani AF \& AbdAllah EF (2018). Antibacterial activity of selected medicinal plants of northwest Pakistan traditionally used against mastitis in livestock. Saudi J Biol Sci 25: 154-161.

25. Masoodi MH, Ahmed B, Zargar IM, Khan SA, Khan S \& Singh P (2008). Antibacterial activity of whole plant extract of Marrubium vulgare. Afr $J$ Biotechnol 7(2): 86-87.

26. Cheruiyot KR, Olila D \& Kateregga J (2009). In-vitro antibacterial activity of selected medicinal plants from Longisa region of Bomet district, Kenya. Afr Health Sci 9: 42-46.

27. Siddiqui A, Akbani S, Zaheer S, Riaz A \& Naheed S (2017). Antimicrobial potential of the leaves, branches and peels of some medicinal plants against various pathogenic microorganisms. FUUAST J Biol 7(1) : 19-22.

28. Begum HA \& Yaseen $T$ (2015). Anitmicrobial, phytochemical, ethnobotanical and proximate analysis of Allium cepa L. J of Adv Bot and Zool 3(1): 1-4.

29. Najjaa H, Zerria K, Fattouch S, Ammar E \& Neffati M (2009). Antioxidant and antimicrobial activities of Allium roseum L. " LAZOUL", a wild edible endemic species in North Africa. Int J Food Prop (LJFP-2009-0049.R2) (In press). 